\title{
Active Ageing Profiles among Older Adults in Spain: A Multivariate Analysis Based on SHARE study
}

\section{Fermina Rojo-Pérez ( $\nabla$ fermina.rojo@csic.es )}

Spanish National Research Council: Consejo Superior de Investigaciones Cientificas https://orcid.org/00000001-9935-2548

\section{Vicente Rodríguez-Rodríguez}

Spanish National Research Council: Consejo Superior de Investigaciones Cientificas

\section{María Ángeles Molina-Martínez}

Universidad Francisco de Vitoria

\section{Gloria Fernández-Mayoralas}

Spanish National Research Council: Consejo Superior de Investigaciones Cientificas

\section{Diego Sánchez-González}

Universidad Nacional de Educación a Distancia: Universidad Nacional de Educacion a Distancia

José Manuel Rojo-Abuín

Spanish National Research Council: Consejo Superior de Investigaciones Cientificas

\section{Alba Ayala}

Universidad Carlos III de Madrid

\section{Carmen Rodríguez-Blázquez}

Carlos III Health Institute: Instituto de Salud Carlos III

\section{Amaia Calderón-Larrañaga}

Karolinska Institutet

\section{Oscar Ribeiro}

University of Aveiro: Universidade de Aveiro

\section{Maria João Forjaz}

Carlos III Health Institute: Instituto de Salud Carlos III https://orcid.org/0000-0003-3935-962X

\section{Research Article}

Keywords: active ageing pillars, active ageing profiles, quality of life, living conditions, sociodemographic factors, SHARE, Spain

Posted Date: February 23rd, 2022

DOI: https://doi.org/10.21203/rs.3.rs-1231572/v1

License: (c) (7) This work is licensed under a Creative Commons Attribution 4.0 International License. Read Full License 


\section{Abstract}

Background. Following the active ageing model based on the Health, Lifelong Learning, Participation and Security pillars, this research has a twofold objective: i) to classify older adults according to active ageing profiles, taking into account the four pillars, and ii) to ascertain the relationship between the profiles and personal and contextual factors, as well as well-being and quality of life in old age.

Methods. A study sample of 5,566 Spanish older adults who participated in wave 6 of the Survey of Health, Ageing and Retirement in Europe (SHARE) was included. Data were analysed in different steps applying several statistical analysis (Principal Components; Cluster; Discriminant; Multiple Correspondence; bivariate analysis with Pearson chi-square and ANOVA).

Results. Five older adult profiles were obtained (I: with moderate activity; II: quasi-dependents; III: with active ageing-limiting conditions; IV: with diverse and balanced activity; $\mathrm{V}$ : with excellent active ageing conditions). The first three profiles were characterised by subjects with a high average age, low educational level, who were retired or housewives, and who perceived a moderate level of loneliness, satisfaction with the social network and quality of life, as well as having a larger family network, but living in small households or alone. In contrast, the latter two profiles showed better personal and contextual conditions, well-being and quality of life.

Discussion and Conclusions. The multidimensional approach to active ageing followed in this article has revealed the presence of several older adult profiles, which are confined to groups with better or worse active ageing conditions. In this context, if ageing is a process that reflects the previous way of life, intervention priorities will have to consider actions that promote better conditions during the life cycle.

\section{Backgrounds}

Population ageing is a global phenomenon with important regional differences. Scientific evidence had already pointed to this trend across the board (1). In Europe, the over-65s represent more than a quarter of the population, having overtaken the number of teenagers and young people aged between 15 and 24 years old (2). In Spain, the percentage of older adults currently stands at $20 \%$, and is set to keep on rising to $36.8 \%$ in 2050 (2).

Different ageing studies take very approaches to the concept, from the pathological approach to an active or successful ageing perspective $(3,4)$. The ageing process does not occur randomly, but instead is conditioned by biological, psychological, social and contextual factors that influence ageing trajectories (5). At older ages, these conditioning factors can trigger health problems, disability and dependence (6), limiting the quality of life of ageing people $(7,8)$. The challenge is to fight disease and disability, trying to delay them in order to live independently for as long as possible (9). The population's longevity, together with its life expectancy and life trajectory, are key elements for considering that the ageing process is essentially heterogeneous (10). This vision of old age is reflected in the strategies for promoting positive ageing trajectories (11), which enhance people's autonomy and independence and their capacities for action as social agents. An example of this is the World Health Organization (WHO) Active Ageing (AA) paradigm $(12,13)$. There are also numerous studies that underscore the importance of specific aspects such as learning $(14,15)$ and the use of information and communication technologies $(16)$ in empowering older adults.

AA is construed as the process of optimising opportunities for Health, Lifelong Learning, Participation and Security in order to improve ageing people's quality of life (17). The model, which underpins a wide range of studies (12, 
13), identifies determinants such as culture, gender, behavioural factors, personal factors, physical and social environment, economic factors, and health and social services. General research proves the consistency of a multifactorial model (18). Different studies base their approach on three key premises: 1) AA is defined as multidimensional, both in its pillars and in the indicators that make up each of them; 2) these dimensions are influenced by a variety of cross-cutting, personal and contextual determinants; and 3) the result of the AA process is an improvement in quality of life $(5,19)$.

The WHO model-based AA analysis follows three main guidelines. The first emphasises the four pillars, though they are not developed to the same extent, as a result of the different amount of available data used in the quantitative methodology, as well as the inclusion of the Lifelong Learning pillar after the seminal model (2002 versus 2015). Thus, Health is a widely studied pillar (20), which can be used as an enabling factor for AA $(21,22)$ or as an outcome consistent with an active way of ageing (23-26). The second pillar, Participation, tends to be very widely represented in any of its meanings, from the most general, engaging in activities (27-30), to other more specific, but highly relevant, activities such as volunteer work (31-36). Many of these studies refer to participation to highlight its effects on health, well-being and quality of life. Participation is linked to remaining physically active (23), developing social networks $(37,38)$ or staying on the job market $(39)$ and contributing to productive activities (40). Other pillars of the model, such as Lifelong Learning $(14,15)$ or Security in its different facets $(41)$ do not attract as much progress in the scientific literature, perhaps, again, because the available data do not favour it.

The second guideline is intertwined with the first because certain dimensions are often valued as interactive factors in determining whether a person is actively ageing (42). Thus, along with the most frequently used purely demographic and individual determinants, such as age and gender $(18,21,43-45)$, great importance is attached to others, such as education (46), personal traits of a psychological nature $(47)$, motivation $(19,29)$ or social and cultural values (46). Recently, environmental factors for active ageing, such as collaborative housing (48) or nursing homes as places for care (27), or other factors in the social and political context that explain social inequality, have gained importance $(43,49)$. Finally, outcome variables to which AA has been related are also acquiring relevance, such as happiness, life satisfaction, well-being and quality of life $(5,19,24,50)$, to explain regional disparity in Europe according to their social, cultural and institutional differences $(23,45,51)$.

In this context, the AA model has become part of a stream of research that explores its capacity to generate types of people and geographical spaces, measuring the degree of activity, by means of quantitative variables $(28,50$, 52). In some cases, specific instruments have been used, such as the active ageing index as a measure of inequality in general or between countries $(45,53-58)$. Other studies have attempted to operationalise the AA model empirically, without reaching a consensus on how to formulate it (59). At the same time, there are disparities in the types and number of variables and measures and instruments considered in different quantitative models $(18,60$, 61 ) and qualitative approaches $(29,41)$. In Europe, the SHARE dataset is becoming a reference framework for the comparative study between countries, especially in its longitudinal perspective and with regard to the study of some of the AA pillars and determinants $(62,63)$. In short, and taking into account the AA model's possible limitations, the importance of its multidimensionality marks a line of research that aims to take a more positive approach $(21,64)$, identifying groups of older adults according to how they age. In this context, this study has aimed to i) establish profiles of older adults in Spain according to AA pillars, and ii) examine the relationship between these profiles and personal and contextual factors, as well as well-being and quality of life.

\section{Methods}




\subsection{Data source, study design and sample}

This study has used the SHARE dataset $(63,65,66)$, a representative study of the European countries in which it is carried out. Ever since it was created in 2004, SHARE has become an infrastructure for researching and understanding population ageing in Europe from a life-course perspective using a multidimensional and longitudinal approach, although not all countries participate in this network. The target population is anyone aged 50 and over who lives in the country in question on a regular basis. Information is collected through ComputerAssisted Personal Interviewing (CAPI), and is harmonised using a questionnaire that is translated into national languages. Data is collected and produced by modules, and an identifier is used to link data (individuals, households) by wave and/or by module. More information on how the data are collected, eligibility population, sampling procedures and documentation for each participant country, types of respondents, ethical standards, sampling and other technical issues can be seen in the edited book by Börsch-Supan and Jürges (67).

This cross-sectional study is based on wave 6 (SHARE W6), release 6.1 .0 (http://www.share-project.org/datadocumentation/share-data-releases.html) (68), in which 17 European countries and Israel took part. The fieldwork was completed in 2015 (69). The data are structured in a set of thematic files, which have been fully reviewed for the selection of the variables of interest in this research. Where available, variables, indices or scales generated by the SHARE project were also used (68); otherwise, the original variables were used. Participants were retained for Spain $(n=5,566)$.

In line with the AA model and its pillar structure, variables from all four pillars, (Health, Lifelong Learning, Participation and Security) $(17,42)$ were used. The authors together reviewed the files, selected the variables and their assignment to the AA pillars in order to reach a consensus. Thus, physical, sensory and mental health, functioning, support and health services utilization variables were selected for the Health pillar. The Lifelong Learning pillar consists of information about educational or training courses and skills. The participation pillar is devoted to information on leisure and community activities participation. Finally, the security pillar includes variables related to household economics. Variables reporting personal characteristics, area of residence and perceptions of well-being and quality of life, as well as life satisfaction, were also used. For the study of quality of life, we used the CASP-12 scale, a revised and adapted version of the CASP-19 instrument on quality of life in older adults. This is a synthetic indicator, based on the theory of human needs $(70,71)$, which measures the extent to which older adults' needs are satisfied in four dimensions: control, autonomy, self-fulfilment and pleasure. The instrument facilitates comparability regardless of the context in which the information is collected (72). Its discriminatory and explanatory capacity (73) shows that it is an effective tool for measuring quality of life in old age beyond the physical and mental capacities of older adults (74).

The variables selected and used, as well as their characteristics, can be seen in Table A (Additional file 1). Variables with more than $10 \%$ of cases with missing value after weighting were eliminated from the analyses, except for the scale of social connectedness $(66,75)$ that reported $10.6 \%$ of missing cases. Information regarding financial gifts and help was discarded from the analysis due to high floor effect that can lead to biased results (76).

\subsection{Statistical analysis}

All analyses have been run with SPSS v26. Based on the cross-sectional calibrated weights for individuals, that reproduced the size of the national target population (68), relative or normalised weights have been calculated by 
dividing the weight by the mean of weights and preserving the sample size (77). When using the normalised weights, the estimates of means and proportions are correct and the test statistics are not affected.

The variables have been recoded so that more positive conditions take higher values. However, the variables relating to perception of loneliness, units of alcohol consumed, limitations (activities of daily living, instrumental activities, mobility), depression, use of the hospital service (number of times and nights), number of illnesses, number of medications taken, number of technical aids used (such as a cane or walking stick, a zimmer frame or walker, etc.), pain intensity scale, number of reported pains and number of frailty symptoms operate in the opposite direction (i.e. the higher the value, the worse the condition) (see Table A, Additional file 1).

The statistical analysis was carried out in five phases:

a) Firstly, the factor analysis technique was applied with the Principal Component Analysis (PCA) extraction method (78) to examine the relationship between the variables selected for the conformation of the AA pillars and reduce their dimensionality. Due to the complexity of the study objective and, especially, the high number of variables required, a PCA was carried out for each thematic set of variables according to the AA pillars (Health, Lifelong Learning, Participation and Security). The factor scores of the 18 Principal Components (PCs) of the four AA pillars obtained were retained in the data file to be used in the next analytical phase.

b) The second phase consisted of applying Cluster Analysis (CLA) to obtain a homogeneous grouping of older adult subjects according to each of the AA pillars, using the K-Means algorithm, where " $k$ " refers to the number of groups specified a priori by the analyst (78). Due to the high number of PCs, and following the analytical method of grouping variables from the previous PCA, a CLA was performed for each AA pillar. In the Health, Lifelong Learning and Security pillars, the initial cluster centroids were chosen randomly by the programme (default option). However, in the Participation pillar the solution chosen by the programme was not satisfactory, as almost all participants were clustered around the mean. Thus, taking into account the factor structure, a solution was proposed in which the initial centroids were provided so that they saturated in the first four PCs of the pillar (PC-11 to PC-14), leaving the last one (PC-15) in the mean (see components of this pillar in Table B (Additional file 2). The classification obtained by CLA was validated by Discriminant Analysis.

c) The clusters resulting from CLA for each AA pillar were used in a third analytical phase to obtain the types of the cluster categories by applying Multiple Correspondence Analysis (MCA). This multivariate method is similar to PCA but for categorical variables, and allows us to ascertain the type of variables from a multidimensional perspective (79). MCA analyses relationships between variables by representing the categories in a multidimensional space (80), so that the distance between categories is used to establish the degree of similarity and plot a perceptual graph (81), in which proximity between categories indicates association, while remoteness is interpreted as independence.

d) Using the MCA category types, the fourth step was to assign each subject or participant in the study to the corresponding AA profile, using the mean of the categories that formed each type in the two MCA dimensions. These means served as centroids in performing a subsequent CLA without centroid updates, so that each subject was assigned to the closest type of categories. This resulted in a classification of subjects by AA profiles to be used in the subsequent analytical phase.

e) Finally, to address the second objective of this study, i.e. to determine the relationship between AA profiles and socio-demographic factors and quality of life conditions, bivariate statistical analysis was applied (contingency 
tables with $\chi 2$ test) with categorical variables. Furthermore, with the scale variables, an ANOVA (with Bonferroni test for multiple comparisons) was conducted to compare the AA profiles in each independent variable. Statistical significance levels were set at $p<.05$.

\section{Results}

\subsection{Sample characteristics}

The sample consisted of 5,566 participants (Table 1), with a mean age of 67.2 years, (Minimum, Min: 51; Maximum, Max: 106; Mean Standard Error, MSE: 15), 53.8\% of whom were women. This sample remained in the education system for an average of 8.8 years (Min: 0; Max: 25; MSE: 0.1), such that $39.4 \%$ of the people completed their primary education or the first stage of basic education, and $23 \%$ secondary basic education (lower or second stage). As regards activity, $38.8 \%$ of the subjects were retired, but almost a quarter remained active, and slightly less than 3 out of 10 were engaged in housework. Two thirds of the older adults were married or living with a partner, and the average household size was 2.2 members.

In residential environment terms, almost two thirds of the older adults resided in large or small towns and half of them occupied dwellings in block buildings (3 or more flats), though more than 4 out of 10 reported living in a block building.

As for other living conditions, older adults showed a mean loneliness score of 3.7 (Min: 3; Max: 9; MSE: 3.7) (the higher the index, the higher the loneliness), and a mean quality of life score (CASP-12) of 36.1 (Min: 12; Max: 48; MSE: 36.1) (higher numbers implying better quality of life). The level of satisfaction with life in general and with the social network obtained mean values of 7.5 and 8.9 , respectively (measured on a scale from 0 : completely dissatisfied to 10: completely satisfied).

\subsection{Investigating the relationship among the variables}

The PCA performed for each AA pillar provided 18 principal components (see Table B, Additional file 2). The Health Pillar-related PCA was formed by 8 PC, explaining $65.7 \%$ of the variance. The Lifelong Learning Pillar showed 2 PCs explaining an $81.2 \%$ of the variance. In the Participation Pillar, $29 \%$ of the participants had no complete information, thus each variable with missing values was replaced with the mean of the variable; 5 PCs were retained explaining a $69.9 \%$ of the variance. Finally, in the Security Pillar formed by economic variables, an overall $69.3 \%$ of the variance was explained by 3 PCs.

\subsection{Grouping participants based on the Active Ageing pillars}

Applying CLA with the PCs for each AA pillar resulted in 17 clusters (Table 2).

a) The CLA performed over the Health Pillar's $(\mathrm{H})$ main components resulted in 5 clusters: $\mathrm{H}-1$ : Need of help for functioning (grouped $32.2 \%$ of the subjects); $\mathrm{H}-2$ : Moderate health (51.5\%); H-3: Bad health (6.6\%); $\mathrm{H}-4$ : Unhealthy habits (8.9\%); $\mathrm{H}-5$ : High hospital use (0.8\%). Consumption of a protein diet and alcohol is a main component that did not stand out in any of the homogeneous groups, as in all of them it is around the mean. Based on Discriminant Analysis we observed that $98.2 \%$ of originally grouped participants were correctly classified.

b) The CLA performed over the Lifelong Learning Pillar's $(L)$ main components grouped subjects in 4 clusters: $L-6$ : Low competence (classified 51.7\% of cases); L-7: Competence and training involvement (3.2\%); L-8: High 
competence (42.3\%) as the opposite group to L-6; L-9: High training involvement (2.8\%). 99\% of originally grouped participants were correctly classified.

c) The CLA performed over the Participation Pillar resulted in 4 clusters (P), named as follows: P-10: Low social connectedness / moderate volunteering (34.9\% of cases); P-11: Low physical \& moderate social-political activities (20.9\%); P-12: Physical activities / social connectedness (28.2\%); P-13: Cognitive activities (16.0\%). The 96.5\% of originally grouped participants were correctly classified.

d) The CLA performed over the Security Pillar's main components captured 4 clusters: S-14: Optimal household economy (classified 3.1\% of cases); S-15: Self-assessed high economic status (38.9\%); S-16: Self-assessed low economic status (57.8\%) contrasts with the previous group; S-17: High value of non-liquid assets $(0.2 \%) .99 .6 \%$ of originally grouped participants were correctly classified.

\subsection{Active Ageing profiles}

The MCA gave a perceptual map with the solution obtained in the clustering of profiles according to their AA pillarrelated living conditions. Figure 1 shows the distribution of the cluster categories on the plane formed by the coordinate axes. The perceptual map showed two dimensions with eigenvalues, or part of the variance explained in each dimension, higher than 1 (dimension 1: 1.721; dimension 2: 1.245) and together they accounted for $37.1 \%$ of the model variability. The relationship of the categories on the plane shows several different subject profiles which, by convention, have been listed starting with the lowest dimension 1 or $x$-axis value, resulting in a counterclockwise grouping. The first three profiles are to be found on the lowest scores of dimension 1, as opposed to the rest of the profiles, to be found on the positive values.

Profile I (people with moderate activity) included subjects with a low participation in physical activities, together with a moderate frequency of social and political activities, and at the same time an optimal economic assessment of their household according to the level of income.

Profile II (quasi-dependent persons) was characterised by poor health and functioning conditions and frailty and, consequently, by the use of health services (primary and hospital care), and the need for help from others in activities of daily living, as well as the use of technical aids. This profile is only associated with the Health pillar.

Profile III (people with active ageing-limiting conditions) grouped subjects with low self-assessed competence in reading, writing and computer skills, low consumption of fruit/vegetables and high consumption of alcoholic beverages, as well as a moderate perception of sensory health (unhealthy habits cluster), low self-perception of household economic status, low social connectedness and moderate participation in voluntary activities. This profile is associated with the four AA pillars.

Profile IV (people with diverse and balanced activity) was characterised by grouping subjects with a high level of competence in reading, writing and computer skills, a moderate state of health together with no need for technical or care aids, and a high frequency of participation in activities requiring moderate or vigorous physical ability, low participation in cognitive activities and moderate to high social cohesion.

Profile V (people with excellent active ageing conditions) brought together subjects who were relatively more heterogeneous than in the previous profiles, so the cluster category centroids are further apart in the perceptual map. This profile represents subjects with a high frequency of educational or training courses attendance and of 
performing cognitive activities, a very high level of financial assets or illiquid goods, as well as a high economic self-positioning of the household.

In the perceptual map there were two clusters, $\mathbf{H - 5}$ (older adults with high hospital service use) and L-7 (people with high level of competence and participation in learning courses) not clustered and distanced from the centre of the coordinate axes $(0,0 ; 0,0)$, which showed little association with other AA profiles.

Profile I clustered $12.7 \%$ of participants, profile II $8.1 \%$, profile III $32.0 \%$, profile IV $30.4 \%$ and profile V $12.8 \%$. The non-grouped clusters ( $\mathrm{H}-5$ and $\mathrm{L}-7)$ classified $0.8 \%$ and $3.2 \%$ of the participants, respectively.

\subsection{Relationship between Active Ageing profiles and sociodemographic, contextual, and quality of life conditions}

The results indicated a statistically significant association with all the variables analysed, and showed two behaviours depending on whether the mean values of the AA profiles were above or below the overall mean value (Figure 2). Thus, subjects in profiles I, II and III, as well as cluster $\mathbf{H}-\mathbf{5}$, were characterised by being older than average, having been in the education system for fewer years (well below the average of 8.8 years), showing a higher than average level of perceived loneliness, and lower satisfaction with their social network (except profile III) and life in general, as well as lower quality of life and subjective well-being. In home and family terms, these subjects live in small households (except profile III), and reported having an above-average number of children and grandchildren (2.2 and 2.1, respectively).

At the other end of the scale were profiles IV and $\mathbf{V}$ together with cluster L-7. These persons were younger (below average, 67.2 years), stayed in the educational system for more than 8.8 years on average (cluster L-7 being an extreme case as it almost doubled this average value), did not report perceiving loneliness, and achieved a higher level of satisfaction with the social network and with life as a whole, as well as a higher quality of life and subjective wellbeing.

Table 3 shows the comparison of means between the profiles, where values not sharing the same subscript (a, b, c, d, e) are significantly different. Consequently, age-related differences were observed between all AA profiles, except for cluster $\mathbf{H}-\mathbf{5}$, which showed no statistically significant differences with profile I (they share the same subscript), and cluster L-7, which also showed no differences with profile IV.

Two scenarios were also observed in terms of categorical variables (Table 4): on the one hand, subjects in profiles I, II and III and cluster H-5, and, on the other, profiles IV and V and cluster L-7, although with some specific differences, such as those concerning gender, with a predominance of women in almost all profiles, of widowed people and to a lesser extent of single and divorced people. In line with the lower number of years spent in the educational system, there were more subjects from the first set of profiles (I, II, III, group H-5) in the lower levels of education, with a predominance of retirees and people with some kind of disability (permanently sick), unemployed and people engaged in housework, living in single-person households, more in single-family dwellings and even in old people's homes (profile I and cluster H-5). Profiles IV and V and cluster L-7 were characterised by having a high level of education, being married or divorced, still in employment, although they were also retired or engaged in housework, lived in households with their partner, or in households with their partner and with other people.

As for the size of the area of residence, almost two thirds of the population lived in medium-sized and large urban areas, and no clearly distinct pattern was observed between profiles I, II and III versus IV and V, as was the case with the type of residence building (3 or more storey-buildings in more than half of the cases). As for dwelling 
tenure status, more than 9 out of 10 older persons owned their dwelling, a status that was higher in profiles III to V, and clusters $\mathrm{H}-5$ and L-7.

\section{Discussion}

This study establishes older adult profiles according to the four AA pillars in Spain, and studies relationships between AA profiles and personal and contextual factors, well-being and quality of life. By doing so, it fills a gap in previous research: in scientific literature, the lack of consensus on formulating the AA model has been conditioned by discrepancies in materials and methods from a multidimensional perspective $(59,60)$.

As regards the first objective, consideration was given to AA's multidimensionality based on the construction of four pillar-related indicators: Health, Lifelong Learning, Participation and Security. The aim was to overcome reductionist approaches that do not address the theoretical model or others that do not distinguish between construct criteria and determinants (64), in order to consider other analytical or methodological approaches, such as the generation of the active ageing index (82) the empirical validation of the AA model (18) or the study of AA and its impact on survival (24).

Each pillar was built with multiple indicators from the SHARE dataset $(63,65,66)$. Other authors, working with the same survey $(24,74,83)$ or with other data $(18)$, arrived at a similar selection of health domain-related indicators (diseases, dependency and physical or cognitive functioning) (84). This paper has expanded the health-related indicators by adding others linked to the use of medical services (85), nutrition (86) and alcohol consumption (87); all of them have been related to functionality, morbidity and/or mortality (85-87). As regards the Participation pillar, SHARE provides information on the type of activities carried out and their frequency, usually considered by most authors (88-92). For the Lifelong Learning pillar, consideration was given to basic skills (reading, writing or computer use) and involvement in training activities (93), while in the Security pillar, measures related mainly to financial security were considered, due to the limitation of the source. Other studies have approached Security as a

pillar of manageable living conditions, such as physical security in the face of dependency (94), or the intuitive and lay understanding of older adults themselves (41).

The analytical procedure for handling all the information was planned and executed in successive phases, starting with the identification of patterns of relationships between variables based on principal component analysis. The cluster analysis conducted for each AA pillar has reflected how different older adults are as they grow older, revealing a wide variety of old age states, as the result of a process in which opportunities are used unequally within each pillar, as stated in the very definition of AA $(17,42)$. Furthermore, this very powerful analytical technique is influenced by the data set used and the research strategy (95). The resultant classification is similar to that obtained in other available reports (96). For instance, more than half of the subjects were classified in the "moderate health" cluster of the Health pillar. According to the National Health Survey (97), 45.5\% of older adults in Spain regard their health to be good or very good. Slightly more than half of the older adults were grouped in the "low competence" cluster of the Lifelong Learning pillar; according to the same report, there is a predominance of older adults with primary education and no education (96). As for the Security pillar classification, the fact that almost $60 \%$ of the subjects are grouped in the "Self-assessed low economic status" cluster could be explained by the volume of inactive population in the sample studied (around $24 \%$ were still employed) and the effect of retirement on income (98). This is in line, firstly, with the individuals' own self-perception of their financial resources (99) and the reported difficulties in making ends meet, which are particularly noticeable in Eastern and 
Southern European countries (100), and, secondly, with the fact that they are close to the poverty line (96) which could be a limiting factor in promoting AA and enhancing the quality of life of older adults.

An optimal combination of the Health, Lifelong Learning, Participation and Security pillars will be key to achieving AA. Most authors hold this assumption and there have been attempts to build it into empirical models (101-103), yet few have succeeded in showing the interdependence between some pillars and others to show profiles of older adults ageing along diverse trajectories. This paper has demonstrated the interdependence of the pillars, giving five main profiles, which in turn were related to personal and contextual factors as well as to measures of well-being and quality of life.

Worth noting is that engaging in activities is present in all profiles except the one defined only by the Health pillar (profile II). Health, through the multiple measures used, either as a factor or as an outcome, is another area that is closely linked with the activity profiles. Indeed, a low perception of health, a limited level of functioning and unhealthy habits lead to less activity among older adults $(28,104)$, while more favourable health conditions encourage leisure and participation activities, such as volunteer work $(33,105)$. This is probably due to the fact that Participation is a cornerstone of the AA framework $(92,106)$ and is a defining element, as opposed to other related terms such as successful, productive, or positive $(47,84)$. Moderate or high participation is related to moderate health and economic conditions. These variables are associated in a multitude of studies and their interdependence is clearly evident $(52,107,108)$. Health and Security seem to be the necessary elements $(22$, 41) underpinning Participation (106). In addition, better conditions in the Lifelong Learning pillar (15) were related to higher activity profiles.

By analysing profiles of older adults in Spain, this research has identified a wide range of factors that give them interpretative consistency, but which do not always match those offered in AA literature, either because they do not follow the same theoretical basis or because they do not always use the same analytical methodology. That is why the AA profiles are constructed with quantitative methods that combine independent variables, generally at the individual level, with others that express the results of the AA process or other related facts, such as quality of life or subjective well-being as outcome variables. As a consequence, it is often hard to clearly distinguish between dimensions, determinants and outcomes, because the analyses are too closely linked to the available data. However, so of the many different factors that influence older adults' active behaviours are far more prevalent than others.

The basic demographic variables, age and gender, are part of the most common interpretative construct because they feature in all studies, whatever their type. Age plays a preferential role, yet it tends to act in two directions: firstly, by appearing in the least active groups (109) and, secondly, by influencing the reduction in the number and type of activities as the population ages $(28,52)$, although it is not always documented to work this way $(110)$. Similarly, the age variable shows a different association by type of active elderly, depending on whether the activities are carried out at home (at older ages) such as family help or home maintenance, or outside the home (at younger ages) such as volunteer work (95). The fact is that, by including other age-related variables, this activity trajectory is also related to living without a partner, with lower economic income (104) and a decrease in personal well-being (50).

Women's involvement is greater in some specific profiles, such as those involving caring for people or activities in the home, or less when it comes to profiles of people still linked to the world of work or volunteer work $(95,109$ 111). In the case of Spain, the life trajectory of these post-Civil War (post-1939) generations, marks an appreciable 
difference in gender roles, although recently women seem to be more interested in carrying out 'novel' and motivating activities, which are more rewarding and which allow them to recover a role hitherto not usually assigned to them (29). Men of these generations behave more conservatively and are more attached to the closer and less active social community space.

The level of education, measured by the number of years spent in the system and the level attained, is another factor that conditions the activity profile, through general rules: a lower educational level tends to be associated with less activity $(28,110)$ and less rewarding or motivating activities, but of a compulsory nature in the family sphere (110). The profiles obtained also show intergenerational educational level-related gains. For instance, profiles IV and V are more defined by the Lifelong Learning profile, with younger ages and a higher level of education. Different studies point to the country's older adults having higher levels of education, making it possible to reduce the gender gap in old age (112).

From a life course perspective, the population studied includes people who are old enough to be retired from work or who are carrying out household tasks, as the main activity-related groups. Both can guide their transition into retirement through a variety of possibilities (113), from those requiring remuneration to those undertaken on a voluntary basis (114) or to maintain intergenerational care relationships (115). However, activity-relatedness is not a factor in many AA studies, probably because of the limited ability to discriminate if the vast majority of the population is already retired or because it is mediated by other variables such as age (116). However, this factor becomes relevant when analysed together with many others to relate AA to quality of life $(48,56)$.

Another way of influencing activity is through concomitant variables, such as level of income, so that education and economy are associated in determining activity profiles (105), or marital status to indicate that people who live alone and have a low level of education behave in a similar way (95). Precisely, beyond marital status, the form of cohabitation, the size of the household and having children and grandchildren are relevant variables in the differential characterisation of activity profiles. The key could be found in whether there are children (or even grandchildren) in the household, or within the family network but living outside the household, in more or less close environments and with more or less frequent contacts in an ascending familialism or supportive-at-distance typology (117). In the first case, a larger household size and reporting having few children and grandchildren is consistent with a profile of younger people, and, in general, men, people living in a couple and with others, possibly children yet to be emancipated, who maintain a diverse and balanced activity (profile IV). Something similar happens with profile $\mathrm{V}$, but in this case they would be women. At the same time, having more children and grandchildren corresponds to low activity profiles (profiles I and II): people living alone, in smaller households, older and, above all, women. Yet having more children and grandchildren could also tend to lead to activities in the home or family care environment that compete with other leisure and participation activities for the person's available time, in order to reconcile tasks of different types and nature (110). The latter could be the case of the profile of limiting conditions for AA (profile III), which is observed among not very old women who say that they have more children and grandchildren both inside and outside the home, and which would also correspond to a descending familialism typology and activity based on intergenerational family solidarity provided by older women (118). In any case, profiles I, II and III show higher reported loneliness, compared to lower scores for profiles IV and V, which would be related not so much to the size of the family network but rather to other factors such as increasing age and changes and lost in marital status, income, self-rate health, cognitive functioning and depression $(119,120)$, aspects that are also related to limiting conditions for AA and maintaining a good quality of life (121). 
Personal motivation (or a lack thereof) as well as personal rewards (life satisfaction) and social rewards (social networks, avoidance of loneliness) also contribute to understanding the active behaviour of older adults (106). It has been found that having a higher number of people in one's social network is associated with higher levels of activity, while a less dense network is associated with lower activity, although perceived support may act in the opposite direction $(28,104)$. On the other hand, the importance of the social and community environment in which the activities are carried out must be assessed as a mechanism for reinforcing them (106).

As regards other contextual conditions, older adults tend to reside in cities, especially medium-sized ones(122), which mirrors the process of urbanisation and demographic ageing (123-125). In this study, no homogeneous pattern has been observed according to the two large profile groups, such that both profile I and $V$ subjects reside in large urban and metropolitan areas, while the remaining ones do so in smaller cities. In any case, the trend towards urbanisation has led to the development of a specific city friendliness programme in order to optimise the living conditions and quality of life of older adults $(30,126)$.

With respect to the residential environment, home ownership is the most significant regime in Spain compared to other neighbouring countries (127), and among the older population it reaches higher proportions in line with their age and the time they have had to acquire it (128). The results show that people with the worst AA conditions (profiles I, II and III, located in the low scores of dimension 1 of the perceptual map) showed slightly lower percentages of ownership compared to the profiles of better positioned subjects, in accordance with their greater purchasing power. In relation to the type of residence dwelling, two situations were observed; on the one hand, older adults with a moderate active profile, living to a greater extent on a farm or in family housing, in line with their location in smaller residential areas, and, on the other hand, the profiles of younger people with better AA conditions, living in housing in block buildings in line with their settlement in large cities and metropolitan areas. In Spain, part of the older population faces the problems of an ageing housing stock characterised by a lower level of amenities (lifts, heating, air conditioning) and the need for renovations, which worsen their isolation, hinder the desire to grow old at home with autonomy and independence, and jeopardise the promotion of AA $(128,129)$.

Other factors may also influence the level of activity, but their effects are not differentiated because they are incorporated into the more general variables. Something very similar happens when we try to measure the impact of carrying out more or less activities of one type or another on personal well-being, quality of life or satisfaction with it. These are very general social and multidimensional constructs, in which it is not the influence of all their conditioning factors is not easily identifiable, and their effects may be contradictory depending on the research design and the data used $(50,130)$. The relationship between AA and personal well-being (including life satisfaction, quality of life, satisfaction with social networks, absence of perceived loneliness) has been highlighted in the profiles of older adults who are more competent and with better personal and contextual conditions to have a high level of activity, in line with the high association of these constructs $(19,92)$.

Constructing an ageing model based on a broad set of variables, in order to identify profiles of older adults with different degrees of activity, is a significantly increasing trend in the literature, and one that uses a methodology based on individual data with multidimensional variables: some that measure different activities, the "process" variables (130) while others measure the person's situation and which the AA model accepts as determining factors. Yet the multidimensional approach is also entails far more complex, as this paper has shown with regard to the construction of AA profiles. The use of quantitative data, from SHARE or other European and North American databases, has highlighted the potential of this classification strategy, both in terms of the activities analysed and the determinants that serve to explain the types of activity and/or profiles of older adults, measured from different

Page 12/28 
perspectives (individual, countries) and supported by different theories $(28,38,50,52,92,109,110,131-133)$. This paper has also revealed a far from negligible diversity of results influenced by the population samples and the variables selected and available for analysis $(104,133,134)$. Furthermore, one must not lose sight of the interpretative capacity of using qualitative information in the study of AA profiles (29). The tendency, however, is that the WHO AA model is not usually considered as the reference to be followed in studies on activity profiles and older adults, and when it is, not all dimensions and determinants are covered (133). It is much more common to use various unidimensional, multidimensional or behavioural models, according to Boudiny (135), based on successful, healthy or productive ageing theories, using specific sources that do not make it easy to standardise results. The sample of studies cited above are good evidence of this.

\section{Limitations and future lines}

It must be noted that this research was subject to certain limitations. The first stems from the difficulty of finding data on active ageing (136). This study used a database, the SHARE project, which is characterised by its rich multidimensional design, and the fact that it studies a large number of countries, thus permitting cross-sectional and longitudinal comparative studies. However, this survey is not designed to specifically survey AA. So, from a thematic approach, this dataset does not offer all the information defined in the AA paradigm $(17,42)$. In this regard, an unequal number of variables have been used per pillar, which also conditions the different number of variables involved in its construction, on the one hand, and a possible bias in the results, on the other.

The larger number of indicators available in the SHARE survey matches the areas of greatest scientific development within AA, namely Health and Participation, with a lower presence of questions related to the Lifelong Learning and Security pillars, despite their proven relevance in positive ageing trajectories $(14,103,137)$.

As regards the variables selected in the Participation pillar, almost $30 \%$ of the participants had missing values. Therefore, during the PCA of this pillar, these values were replaced by the mean of the variable. This may have influenced the results obtained for this pillar in the first CLA run, as almost $95 \%$ of the cases were grouped around a single cluster. This was the reason why, for this set of variables, the initial centroids were user-defined.

Despite these limitations, the research also has certain strengths, including the methodological design to address the study of a large dataset of different types of data. Consequently, the successive analytical procedure phases have been expressly planned and executed for the proposed objectives.

In the multiple and diverse AA studies, there is room for future and novel developments stemming from their conceptualisation and progress and from the aforementioned limitations to achieve more precise diagnoses. Some of the possible improvements in these studies should come from the need to establish comparative frameworks between countries, differentiated by their social, cultural and political model, thus overcoming the reductionism imposed by research anchored in, for example, developed countries. Although this is an increasingly widespread trend, there are two other areas that would require more attention, such as cross-referencing and further triangulation studies. Both would stem from longitudinal type analyses, albeit constrained by the availability of adequate data, and the use of combined quantitative-qualitative methodologies, which would make it easier to compare the two visions and provide deeper insight into the views and experiences of older adults.

Finally, there is another area for improvement in AA research, derived from the use of pre-post methodology, which enables social interventions to first assess and then improve the behaviour of older adults. This knowledge would 
underpin the application of public policies aimed at promoting active ageing as a mechanism for consolidating quality of life in the ageing process.

\section{Conclusions}

This research has revealed the presence of various profiles of older adults according to their levels of AA in Spain. Following the pillars of the seminal WHO model and its subsequent complementation and applying various analytical statistical techniques, five profiles of people have been obtained: with moderate activity, quasidependents, with limiting active ageing conditions, with diverse and balanced activity, and with excellent active ageing conditions. The first three profiles accounted for more than half of the population, their main features being their higher average age, lower level of education, being retired, living in small households but having had more children and grandchildren, showing a greater perception of loneliness and lower quality of life. On the other hand, profile IV and $\mathrm{V}$ subjects were the mirror image of the previous profiles.

With the results obtained, the older adult subjects can be classified into profiles, which could serve as a basis for establishing intervention priorities, although this is not the object of this study. However, the main priority would be to address the foundations for better living conditions in old age throughout the life cycle, from educational stages, working age, retirement age, or other stages with specific needs. As a process, ageing reflects a person's previous way of life (10) and, as a society, possible differences in the life course will lead to social inequalities (138), which are at the origin of a different level of $A A$. As the older adults group grows with the arrival of generations with better living conditions, this age group is likely to achieve better AA profiles in the near future.

\section{Abbreviations}

AA: Active Ageing; CLA: Cluster Analysis; Max: Maximum value; MCA: Multiple Correspondence Analysis; Min: Minimum value; MSE: Mean Standard Error; PCA: Principal Component Analysis; PC or PCs: Principal Component or Principal Components; SHARE: the Survey of Health, Ageing and Retirement in Europe; WHO: World Health Organization.

\section{Declarations}

\section{- Ethics approval and consent to participate}

The SHARE project was reviewed and approved by the Ethics Council of the Max Planck Society. The SHARE data collection procedures are subject to continuous ethics review. SHARE-ERIC's (the Survey of Health, Ageing and Retirement in Europe -SHARE- became the first European Research Infrastructure Consortium -ERIC-) activities related to human subjects research are guided by international research ethics principles such as the Respect Code of Practice for Socio-Economic Research (professional and ethical guidelines for the conduct of socio-economic research) and the Declaration of Helsinki.

\section{- Consent for publication}

Not applicable.

\section{- Availability of data}


Access to the data collected and generated in the SHARE project is provided free of charge for scientific use globally, subject to European Union and national data protection laws as well as the publicly available Conditions of Use. Access to the data is available online (http://www.share-project.org/data-access.html) after user registration.

\section{- Competing interests}

The authors declare no conflict of interest. The funders had no role in the design of the study; in the collection, analyses, or interpretation of data; in the writing of the manuscript, or in the decision to publish the results.

\section{- Funding}

Research of this paper is a part of i) the QASP research project, funded by the Institute of Health Carlos III, Intramural Strategical Action in Health AESI 2018 (PI18CIII/00046); ii) it has also been partially funded by REDISSEC (RD16/0005/0002 and RD16/0001/0005, co-funded by European Regional Development Fund/European Social Fund "A way to make Europe" / "Investing in your future") projects; iii) the R\&D Activities Program ENCAGEn-CM (H2019/HUM-5698) funded by the Community of Madrid and co-funded by the European Social Fund; iv) the ENVACES R\&D+i project (MINECO-FEDER, ref. CS02015-64115-R). Authors acknowledge support of the publication fee by the CSIC Open Access Publication Support Initiative through its Unit of Information Resources for Research (URICI).

\section{- Authors' contributions}

Conceptualization and methods: FRP, VRR, MAMM, MJF; analysis, JMRA, AA, FRP; writing original draft preparation, FRP, VRR, GF-M, MAMM, DSG; review writing and editing, all the authors; project administration and funding acquisition, MJF, GF-M, VRR, FRP. All authors have read and approved the manuscript.

\section{- Acknowledgements}

This paper uses data from SHARE Wave 6 (DOI: 10.6103/SHARE.w6.710), see Börsch-Supan et al. (63) for methodological details. The SHARE data collection has been funded by the European Commission through FP5 (QLK6-CT-2001-00360), FP6 (SHARE-I3: RII-CT-2006-062193; COMPARE: CIT5-CT-2005-028857; SHARELIFE: CIT4CT-2006-028812), FP7 (SHARE-PREP: GA N²11909; SHARE-LEAP: GA Nº 227822; SHARE M4: GA N²61982; DASISH: GA N² 283646) and Horizon 2020 (SHARE-DEV3: GA N 676536; SHARE-COHESION: GA N870628; SERISS: GA N 654221; SSHOC: GA N 823782) and by DG Employment, Social Affairs \& Inclusion. Additional funding from the German Ministry of Education and Research, the Max Planck Society for the Advancement of Science, the U.S. National Institute on Aging (U01_AG09740-13S2; P01_AG005842; P01_AG08291; P30_AG12815; R21_AG025169; Y1-AG-4553-01; IAG_BSR06-11; OGHA_04-064; HHSN271201300071C) and from various national funding sources is gratefully acknowledged (see www.share-project.org).

\section{References}

1. Christensen K, Doblhammer G, Rau R, Vaupel JW. Ageing populations: the challenges ahead. The Lancet. 2009;374(9696):1196-208. doi:10.1016/s0140-6736(09)61460-4

2. UN- United Nations, Department of Economic and Social Affairs, Population Division. World Population Ageing 2019 (ST/ESA/SER.A/444). New York: United Nations, Department of Economic and Social Affairs, Population 
Division; 2020. Available from:

https://www.un.org/en/development/desa/population/publications/pdf/ageing/WorldPopulationAgeing2019Report.pdf. accessed: 04-03-2020.

3. Baltes PB, Smith J. New frontiers in the future of aging: from successful aging of the young old to the dilemmas of the fourth age. Gerontology. 2003;49(2):123-35. doi:10.1159/000067946

4. Rowe JW, Kahn RL. Successful aging. The Gerontologist. 1997;37(4):433-40. doi:10.1093/geront/37.4.433

5. Fernández-Ballesteros R, Sánchez-Izquierdo M, Santacreu M. Active Aging and Quality of Life. In: Rojo-Pérez F, Fernández-Mayoralas G, editors. Handbook of Active Ageing and Quality of Life From Concepts to Applications. Cham: Springer, International Handbooks of Quality-of-Life series; 2021. p. 15-42. doi:10.1007/978-3-030-58031-5_2

6. Costa-Font J, Wittenberg R, Patxot C, Comas-Herrera A, Gori C, di Maio A, et al. Projecting Long-Term Care Expenditure in Four European Union Member States: The Influence of Demographic Scenarios. Social Indicators Research. 2008;86(2):303-21. doi:10.1007/s11205-007-9140-4

7. Akosile CO, Mgbeojedo UG, Maruf FA, Okoye EC, Umeonwuka IC, Ogunniyi A. Depression, functional disability and quality of life among Nigerian older adults: Prevalences and relationships. Archives of Gerontology and Geriatrics. 2018;74:39-43. doi:10.1016/j.archger.2017.08.011

8. Naveiro-Rilo J-C, Diez-Juárez D, Flores-Zurutuza M-L, Javierre-Pérez P, Alberte-Pérez C, Molina-Mazo R. La calidad de vida en ancianos polimedicados con multimorbilidad. Revista Española de Geriatría y Gerontología. 2014;49(4):158-64. doi:10.1016/j.regg.2013.10.004

9. Zaidi A, Gasior K, Zolyomi E, Schmidt A, Rodrigues R, Marin B. Measuring active and healthy ageing in Europe. Journal of European Social Policy. 2017;27(2):138-57. doi:10.1177/0958928716676550

10. Kalache A, Voelcher I, Louvison M. Active Aging and the Longevity Revolution. In: Rojo-Pérez F, FernándezMayoralas G, editors. Handbook of Active Ageing and Quality of Life From Concepts to Applications. Cham: Springer, International Handbooks of Quality-of-Life series; 2021. p. 43-62. doi:10.1007/978-3-030-58031-5_3

11. Walker A, Maltby T. Active ageing: A strategic policy solution to demographic ageing in the European Union. International Journal of Social Welfare. 2012;21(Suppl. 1):S117-S30. doi:10.1111/j.1468-2397.2012.00871.x

12. Rojo-Pérez F, Fernández-Mayoralas G, Rodríguez-Rodríguez V. Active Ageing and Quality of Life: A Systematized Literature Review. In: Rojo-Pérez F, Fernández-Mayoralas G, editors. Handbook of Active Ageing and Quality of Life From Concepts to Applications. Cham: Springer, International Handbooks of Quality-of-Life series; 2021. p. 63-96. doi:10.1007/978-3-030-58031-5_4

13. Rojo-Pérez F, Gallardo-Peralta L, Fernández-Mayoralas G, Rodríguez-Rodríguez V, Montes de Oca Zavala V, Prieto-Flores ME, et al. Envejecimiento activo y buen envejecer en Iberoamérica. Una revisión bibliográfica. In: Fernández-Mayoralas G, Rojo-Pérez F, editors. Envejecimiento Activo, Calidad de Vida y Género Las miradas académica, institucional y social. Valencia: Tirant lo Blanch; 2021. p. 175-211. Available from: https://editorial.tirant.com/co/libro/envejecimiento-activo-calidad-de-vida-y-genero-9788418329142.

14. Molina MÁ, Schettini R. Lifelong Learning and Quality of Life. In: Rojo-Pérez F, Fernández-Mayoralas G, editors. Handbook of Active Ageing and Quality of Life From Concepts to Applications. Cham: Springer, International Handbooks of Quality-of-Life series; 2021. p. 111-9. doi:10.1007/978-3-030-58031-5_6

15. Schettini R, Molina-Martínez MÁ, Gallardo Peralta LP. Formación continua en el proceso de envejecimiento desde una perspectiva popular. In: Fernández-Mayoralas G, Rojo-Pérez F, editors. Envejecimiento Activo, Calidad de Vida y Género Las miradas académica, institucional y social. Valencia: Tirant lo Blanch; 2021. p. 
307-26. Available from: https://editorial.tirant.com/co/libro/envejecimiento-activo-calidad-de-vida-y-genero9788418329142.

16. Martín Palomo MT, Muñoz Terrón JM. Tecnologías de la Información y de la Comunicación en el envejecimiento activo. In: Fernández-Mayoralas G, Rojo-Pérez F, editors. Envejecimiento Activo, Calidad de Vida y Género Las miradas académica, institucional y social. Valencia: Tirant lo Blanch; 2021. p. 409-528. Available from: https://editorial.tirant.com/co/libro/envejecimiento-activo-calidad-de-vida-y-genero9788418329142.

17. WHO- World Health Organization. Active Ageing: A Policy Framework. Geneva: World Health Organization; 2002. 1-60 p. Available from: http://apps.who.int/iris/bitstream/10665/67215/1/WHO_NMH_NPH_02.8.pdf. Accessed: 22-07-2008.

18. Paúl C, Ribeiro O, Teixeira L. Active ageing: An empirical approach to the WHO model. Current Gerontology and Geriatrics Research. 2012(382972):1-10. doi:10.1155/2012/382972

19. Rojo-Pérez F, Fernández-Mayoralas G. Comprensión y autovaloración de la Calidad de Vida como medida de resultado del Envejecimiento Activo. In: Fernández-Mayoralas G, Rojo-Pérez F, editors. Envejecimiento Activo, Calidad de Vida y Género Las miradas académica, institucional y social. Valencia: Tirant lo Blanch; 2021. p. 743-801. Available from: https://editorial.tirant.com/co/libro/envejecimiento-activo-calidad-de-vida-y-genero9788418329142.

20. Win HH, Nyunt TW, Lwin KT, Zin PE, Nozaki I, Bo TZ, et al. Cohort profile: healthy and active ageing in Myanmar (JAGES in Myanmar 2018): a prospective population-based cohort study of the long-term care risks and health status of older adults in Myanmar. BMJ Open. 2020;10(10):e042877. doi:10.1136/bmjopen-2020-042877

21. Bosch-Farré C, Garre-Olmo J, Bonmatí-Tomàs A, Malagón-Aguilera M-C, Gelabert-Vilella S, Fuentes-Pumarola C, et al. Prevalence and related factors of Active and Healthy Ageing in Europe according to two models: Results from the Survey of Health, Ageing and Retirement in Europe (SHARE). PLOS One. 2018;13(10):1-19.

doi:10.1371/journal.pone.0206353

22. Rodríguez-Blázquez C, Martin S, Forjaz MJ. Factores determinantes de la salud en el envejecimiento activo. In: Fernández-Mayoralas G, Rojo-Pérez F, editors. Envejecimiento Activo, Calidad de Vida y Género Las miradas académica, institucional y social. Valencia: Tirant lo Blanch; 2021. p. 213-29. Available from: https://editorial.tirant.com/co/libro/envejecimiento-activo-calidad-de-vida-y-genero-9788418329142.

23. Fass E, Schlesinger T. The Relation of Physical Activity and Self-Rated Health in Older Age - Cross Country Analysis Results from SHARE. Journal of Population Ageing. 2020;13(3):347-64. doi:10.1007/s12062-01909242-w

24. Hijas-Gómez Al, Ayala A, Rodríguez-García MP, Rodríguez-Blázquez C, Rodríguez-Rodríguez V, Rojo-Pérez F, et al. The WHO Active Ageing Pillars and its association with survival: findings from a population-based study in Spain. Archives of Gerontology and Geriatrics. 2020;90(104114):1-15. doi:10.1016/j.archger.2020.104114

25. Litwin H, Schwartz E, Damri N. Cognitively Stimulating Leisure Activity and Subsequent Cognitive Function: A SHARE-based Analysis. The Gerontologist. 2017;57(1): 940-8. doi:10.1093/geront/gnw084

26. Sirven N, Debrand T. La Participation Sociale des Personnes Âgées en Europe. Instrument du «Bien Vieillir » ou Facteur d'Inégalités Sociales de Santé? [Social participation of elderly people in Europe: An instrument of "healthy ageing" or a factor in the social inequality of health?]. Retraite et Société. 2013;65(2):59-80. doi:10.3917/rs.065.0059

27. Fernández-Mayoralas G, Rojo-Pérez F, Martínez-Martín P, Prieto-Flores M-E, Rodríguez-Blázquez C, MartínGarcía S, et al. Active ageing and quality of life: factors associated with participation in leisure activities 
among institutionalized older adults, with and without dementia. Aging \& Mental Health. 2015;19(11):1031-41. doi:10.1080/13607863.2014.996734

28. Morrow-Howell N, Putnam M, Lee YS, Greenfield JC, Inoue M, Chen H. An Investigation of Activity Profiles of Older Adults. The Journals of Gerontology, Series B: Psychological Sciences and Social Sciences. 2014;69(5):809-21. doi:10.1093/geronb/gbu002

29. Rodríguez-Rodríguez V, Rojo-Pérez F, Fernández-Mayoralas G, Prieto-Flores M-E. ¿Cómo interpretan el envejecimiento activo las personas mayores en España? Evidencias desde una perspectiva no profesional. Aula Abierta. 2018;47(1):67-78. doi:10.17811/rifie.47.1.2018.67-78

30. Sánchez-González D, Rojo-Pérez F, Rodríguez-Rodríguez V, Fernández-Mayoralas G. Environmental and Psychosocial Interventions in Age-Friendly Communities and Active Ageing: A Systematic Review. International Journal of Environmental Research and Public Health. 2020;17(22):8305. doi:10.3390/ijerph17228305

31. Haski-Leventhal D. Elderly Volunteering and Well-Being: A Cross-European Comparison Based on SHARE Data. VOLUNTAS: International Journal of Voluntary and Nonprofit Organizations. 2009;20(4):388-404. doi:10.1007/s11266-009-9096-x

32. Morawski L, Okulicz-Kozaryn A, Strzelecka M. Elderly Volunteering in Europe: The Relationship Between Volunteering and Quality of Life Depends on Volunteering Rates. VOLUNTAS: International Journal of Voluntary and Nonprofit Organizations. 2020 first online; . doi:10.1007/s11266-020-00267-w

33. Papa R, Cutuli G, Principi A, Scherer S. Health and Volunteering in Europe: A Longitudinal Study. Research on Aging. 2019;41(7):670-96. doi:10.1177/0164027519834939

34. Potocnik K, Sonnentag S. A longitudinal study of well-being in older workers and retirees: : The role of engaging in different types of activities. Journal of Occupational and Organizational Psychology. 2013;86(4):497-521. doi:10.1111/joop.12003

35. Principi A, Galenkamp H, Papa R, Socci M, Suanet B, Schmidt A, et al. Do predictors of volunteering in older age differ by health status? European Journal of Ageing. 2016;13(2):91-102. doi:10.1007/s10433-016-0377-0

36. Serrat R, Scharf T, Villar F, Gómez C. Fifty-Five Years of Research Into Older People's Civic Participation: Recent Trends, Future Directions. The Gerontologist. 2020;60(1):e38-e51. doi:10.1093/geront/gnz021

37. Litwin $\mathrm{H}$, Stoeckel K. Engagement and social capital as elements of active ageing: an analysis of older europeans. Socilogia e Politiche Sociali. 2014;17(3):9-31. doi:10.3280/SP2014-003002

38. Rossi G, Boccacin L, Bramanti D, Meda SG. Active ageing: Intergenerational relationships and social generativity. In: Riva G, Ajmone Marsan P, Grassi C, editors. Active Ageing and Healthy Living: A Human Centered Approach in Research and Innovation as Source of Quality of Life. Amsterdam: IOS Press. Series Studies in Health and Technology, vol. 203; 2014. p. 57-68. doi:10.3233/978-1-61499-425-1-57

39. Di Gessa G, Grundy E. The relationship between active ageing and health using longitudinal data from Denmark, France, Italy and England. Journal of Epidemiology and Community Health. 2014;68(3):261-7. doi:10.1136/jech-2013-202820

40. Wahrendorf M, Siegrist J. Are changes in productive activities of older people associated with changes in their well-being? Results of a longitudinal European study. European Journal of Ageing. 2010;7(2):59-68. doi:10.1007/s10433-010-0154-4

41. Fernández-Mayoralas G, Rojo-Pérez F, Rodríguez-Rodríguez V, Sánchez-Román $M$, Schettini R, RodríguezBlázquez C, et al. Marco teórico y estudio de diseño e implementación de investigación cualitativa en 
Envejecimiento Activo, Calidad de Vida y Género. In: Fernández-Mayoralas G, Rojo-Pérez F, editors.

Envejecimiento Activo, Calidad de Vida y Género Las miradas académica, institucional y social. Valencia:

Tirant lo Blanch; 2021. p. 48-126. Available from: https://editorial.tirant.com/co/libro/envejecimiento-activocalidad-de-vida-y-genero-9788418329142.

42. ILC-BR- International Longevity Centre Brazil. Active Ageing: A Policy Framework in Response to the Longevity Revolution. Rio de Janeiro: International Longevity Centre Brazil; 2015. 116 p. Available from:

https://ilcbrazil.org.br/wp-content/uploads/2020/07/FINAL-executive-summary-04-v1.1.pdf. Accessed: 16-092021.

43. Molina MÁ, Cañadas-Reche JL, Serrano-del-Rosal R. Social Participation of the Elders in Europe: The Influence of Individual and Contextual Variables. Ageing International. 2018;43(2):190-206. doi:10.1007/s12126-0179300-z

44. Sánchez-Román M, Fernández-Mayoralas G. Género y envejecimiento activo: la visión de los informantes clave en instituciones, equipos profesionales y personas mayores usuarias de servicios. In: FernándezMayoralas G, Rojo-Pérez F, editors. Envejecimiento Activo, Calidad de Vida y Género Las miradas académica, institucional y social. Valencia: Tirant lo Blanch; 2021. p. 585-616. Available from:

https://editorial.tirant.com/co/libro/envejecimiento-activo-calidad-de-vida-y-genero-9788418329142.

45. Steinmayr D, Weichselbaumer D, Winter-Ebmer R. Gender Differences in Active Ageing: Findings from a New Individual-Level Index for European Countries. Social Indicators Research. 2020;151(2):691-721.

doi:10.1007/s11205-020-02380-1

46. Hank K, Erlinghagen M. Dynamics of volunteering in older Europeans. The Gerontologist. 2010;50(2):170-8. doi:10.1093/geront/gnp122

47. Molina-Martínez MA, Schettini R, Fernández-Fernández V, Gallardo-Peralta L. El papel de las variables psicológicas en el envejecimiento activo. Perspectiva no académica. In: Fernández-Mayoralas G, Rojo-Pérez F, editors. Envejecimiento Activo, Calidad de Vida y Género Las miradas académica, institucional y social. Valencia: Tirant lo Blanch; 2021. p. 473-95. Available from: https://editorial.tirant.com/co/libro/envejecimiento-activo-calidad-de-vida-y-genero-9788418329142.

48. Rojo-Pérez F, Fernández-Mayoralas G, Rodríguez-Rodríguez V, Lardiés-Bosque R, Prieto-Flores ME, GallardoPeralta LP, et al. Contextos residenciales, envejecimiento activo y calidad de vida. Un análisis a microescala en España. In: Sempere Souvannavong JD, Cortés Samper C, Cutillas Orgilés E, Valero Escandell JR, editors. Población y territorio España tras la crisis de 2008. Granada: COMARES; 2020. p. 191-208. Available from: http://rua.ua.es/dspace/handle/10045/115389.

49. Lardiés Bosque R. Sociedad, instituciones y políticas: factores para envejecer activamente y con calidad de vida en España. In: Fernández-Mayoralas G, Rojo-Pérez F, editors. Envejecimiento Activo, Calidad de Vida y Género Las miradas académica, institucional y social. Valencia: Tirant lo Blanch; 2021. p. 397-438. Available from: https://editorial.tirant.com/co/libro/envejecimiento-activo-calidad-de-vida-y-genero-9788418329142.

50. Ramia I, Voicu M. Life Satisfaction and Happiness Among Older Europeans: The Role of Active Ageing. Social Indicators Research. 2020 first online. doi:10.1007/s11205-020-02424-6

51. Erlinghagen M, Hank K. The participation of older Europeans in volunteer work. Ageing \& Society. 2006;26(4):567-84. doi:10.1017/S0144686X06004818

52. Arpino B, Bordone V. Active Ageing Typologies: A Latent Class Analysis of the Older Europeans. In: Zaidi A, Harper S, Howse K, Lamura G, Perek-Białas J, editors. Building Evidence for Active Ageing Policies: Active 
Ageing Index and its Potential. Singapore: Springer Singapore; 2018. p. 295-311. doi:10.1007/978-981-106017-5_14

53. Au DWH, Woo J, Zaidi A. Extending the Active Ageing Index to Hong Kong Using a Mixed-Method Approach: Feasibility and Initial Results. Journal of Population Ageing. 2021;14(1):53-68. doi:10.1007/s12062-02009275-6

54. Barslund $M$, Von Werder $M$, Zaidi A. Inequality in active ageing: evidence from a new individual-level index for European countries. Ageing \& Society. 2019;39(3):541-67. doi:10.1017/S0144686X17001052

55. Rodríguez-Rodríguez V, Rojo-Pérez F, Fernández-Mayoralas G, Morillo R, Forjaz MJ, Prieto-Flores ME. Active Ageing Index: Application to Spanish Regions. Journal of Population Ageing. 2017;10(1):25-40. doi:10.1007/s12062-016-9171-1

56. Rojo-Pérez F, Fernández-Mayoralas G, Rodríguez-Rodríguez V. Active Ageing and Personal Wellbeing Among Older Adults in Spain. In: Maggino F, editor. Encyclopedia of Quality of Life and Well-Being Research. Cham: Springer International Publishing; 2020. p. 1-10. doi:10.1007/978-3-319-69909-7_4001-2

57. Varlamova M, Sinyavskaya O. Active Ageing Index in Russia - Identifying Determinants for Inequality. Journal of Population Ageing. 2020;14(1):69-90. doi:10.1007/s12062-020-09277-4

58. Um J, Zaidi A, Parry J, Xiong Q. Capturing gendered aspects of active aging in China: Insights drawn from the Active Aging Index in comparison with EU countries. Asian Social Work and Policy Review. 2020;15(1):47-59. doi:10.1111/aswp.12218

59. Álvarez-García J, Durán-Sánchez A, Del Río-Rama MDIC, García-Vélez DF. Active Ageing: Mapping of Scientific Coverage. International Journal of Environmental Research and Public Health. 2018;15:1-21. doi:10.3390/ijerph15122727

60. Naah FL, Njong AM, Kimengsi JN. Determinants of active and healthy ageing in sub-saharan africa: Evidence from Cameroon. International Journal of Environmental Research and Public Health. 2020;17(9):3038. doi:10.3390/ijerph17093038

61. Thanakwang K, Isaramalai S, Hatthakit U. Development and psychometric testing of the active aging scale for Thai adults. Clinical Interventions in Aging. 2014;9:1211-21. doi:10.2147/CIA.S66069

62. Borsch-Supan A, Hank K, Jurges H, Schroder M. Introduction: empirical research on health, ageing and retirement in Europe. Journal of European Social Policy. 2009;19(4):293-300.

doi:10.1177/1350506809341510

63. Börsch-Supan A, Brandt M, Hunkler C, Kneip T, Korbmacher J, Malter F, et al. Data Resource Profile: The Survey of Health, Ageing and Retirement in Europe (SHARE). International Journal of Epidemiology. 2013;42(1):9921001. doi:10.1093/ije/dyt088

64. Fernández-Ballesteros García R, Zamarrón Casinello MD, López Bravo MD, Molina Martínez MÁ, Díez Nicolás J, Montero López P, et al. Envejecimiento con éxito: criterios y predictores. Psicothema. 2010;22(4):641-7.

65. Börsch-Supan A. Survey of Health, Ageing and Retirement in Europe (SHARE) Wave 6. Release version: 7.1.0. SHARE-ERIC. Data set2019. Available from: http://www.share-project.org/data-documentation/wavesoverview/wave-6.html. doi:10.6103/SHARE.w6.710

66. Malter F, Börsch-Supan A, editors. SHARE Wave 6: Panel innovations and collecting Dried Blood Spots. München: Munich Center for the Economics of Aging (MEA), the Max Planck Institute for Social Law and Social Policy (MPISOC); 2017. Available from: http://www.shareproject.org/uploads/tx_sharepublications/201804_SHARE-WAVE-6_MFRB.pdf. accessed: 23-11-2020. 
67. Börsch-Supan A, Jürges H, editors. The Survey of Health, Aging, and Retirement in Europe - Methodology. Mannheim: Research Institute for the Economics of Aging (MEA); 2005. Available from: http://www.shareproject.org/uploads/tx_sharepublications/SHARE_BOOK_METHODOLOGY_Wave1.pdf.

68. MEA- Munich Center for the Economics of Aging. The Survey of Health, Ageing and Retirement in Europe (SHARE). Release Guide 6.1.0. Mannheim: Mannheim Research Institute for the Economics of Aging (MEA); March 29 2018. 84 p. Available from: http://www.shareproject.org/fileadmin/pdf_documentation/SHARELIFE_release_guide_6.1.0.pdf.

69. Malter F, Schuller K, Börsch-Supan A. SHARE Compliance Profiles - Wave 6. München: Munich Center for the Economics of Aging (MEA), the Max Planck Institute for Social Law and Social Policy (MPISOC); 2016. Available from: http://www.shareproject.org/fileadmin/pdf_documentation/SHARE_Wave6_ComplianceProfiles_v8.pdf. accessed: 22-02-2021.

70. Doyal L, Gough I. A theory of human needs. Critical Social Policy. 1984;4(10):6-38. doi:10.1177/026101838400401002

71. Maslow AH. A theory of human motivation. Psychological Review. 1943;50(4):370-96. doi:10.1037/h0054346

72. Hyde M, Wiggins RD, Higgs P, Blane DB. A measure of quality of life in early old age: The theory, development and properties of a Needs Satisfaction Model (CASP-19). Aging \& Mental Health. 2003;7(3):186-94. doi:10.1080/1360786031000101157

73. Howel D. Interpreting and evaluating the CASP-19 quality of life measure in older people. Age and Ageing. 2012;41(5):612-7. doi:10.1093/ageing/afs023

74. Ayala A, Rodríguez-Blázquez C, Calderón-Larrañaga A, Beridze G, Teixeira L, Araújo L, et al. Influence of Active and Healthy Ageing on Quality of Life Changes: Insights from the Comparison of Three European Countries. International Journal of Environmental Research and Public Health. 2021;18(8):4152. doi:10.3390/ijerph18084152

75. Litwin H, Stoeckel KJ. Social Network, Activity Participation, and Cognition: A Complex Relationship. Research on Aging. 2016;38(1):76-97. doi:10.1177/0164027515581422

76. Šimkovic M, Träuble B. Robustness of statistical methods when measure is affected by ceiling and/or floor effect. PLoS ONE. 2019;14(8):e0220889. doi:10.1371/journal.pone.0220889

77. Hahs-Vaughn DL. A Primer for Using and Understanding Weights With National Datasets. The Journal of Experimental Education. 2005;73(3):221-48. doi:10.3200/JEXE.73.3.221-248

78. Hair JFJ, Anderson RE, Tatham RL, Black WC. Multivariate data analysis. Upper Saddle River, New Jersey: Prentice-Hall; 1998. 730 p.

79. Husson F, Josse J. Multiple Correspondence Analysis. In: Blasius J, Greenacre M, editors. Visualization and Verbalization of Data. New York: Chapman and Hall/CRC; 2014. p. 163-81. doi:10.1201/b16741

80. Di Franco G. Multiple correspondence analysis: one only or several techniques? Quality \& Quantity. 2015;50(3):1299-315. doi:10.1007/s11135-015-0206-0

81. Rodriguez-Sabate C, Morales I, Sanchez A, Rodriguez M. The Multiple Correspondence Analysis Method and Brain Functional Connectivity: Its Application to the Study of the Non-linear Relationships of Motor Cortex and Basal Ganglia. Front Neurosci. 2017;11(345). doi:10.3389/fnins.2017.00345

82. Zaidi A, Gasior K, Hofmarcher MM, Lelkes O, Marin B, Rodrigues R, et al. Active Ageing Index 2012. Concept, Methodology and Final Results. Vienna: European Centre Vienna; 2013. Available from: http://www1.unece.org/stat/platform/display/AAl/Active+Ageing+Index+Home. accessed: 02-09-2013 
83. Hank K. How "successful" do older Europeans age? Findings from SHARE. The Journals of Gerontology, Series B: Psychological Sciences and Social Sciences. 2011;66B(2):230-6. doi:10.1093/geronb/gbq089

84. Fernández-Ballesteros R, Molina M-A, Schettini R, Santacreu M. The semantic network of aging well. In: Robine J-M, Jagger C, Crimmins EM, Robine J-M, Jagger C, Crimmins EM, editors. Annual review of gerontology and geriatrics, Vol 33: Healthy longevity: A global approach. New York, NY, US: Springer Publishing Co; 2013. p. 79107. Available from: http://search.ebscohost.com/login.aspx?direct=true\&db=psyh\&AN=2013-41254005\&lang=es\&site=ehost-live.

85. Li CM, Lin CH, Li Cl, Liu CS, Lin WY, Li TC, et al. Frailty status changes are associated with healthcare utilization and subsequent mortality in the elderly population. BMC Public Health. 2021;21(645). doi:10.1186/s12889-021-10688-x

86. Jayanama K, Theou O, Godin J, Cahill L, Rockwood K. Association of fatty acid consumption with frailty and mortality among middle-aged and older adults. Nutrition. 2020;70:110610. doi:10.1016/j.nut.2019.110610

87. Stott DJ. Alcohol and mortality in older people: understanding the J-shaped curve. Age and Ageing. 2020;49(3):332-3. doi:10.1093/ageing/afaa027

88. Adams KB, Leibbrandt S, Moon $\mathrm{H}$. A critical review of the literature on social and leisure activity and wellbeing in later life. Ageing and Society. 2011;31(4):683-712. doi:10.1017/s0144686x10001091

89. Arpino B, Solé-Auró A. Education Inequalities in Health Among Older European Men and Women: The Role of Active Aging. Journal of Aging and Health. 2017;31(1):185-208. doi:10.1177/0898264317726390

90. Boerio P, Garavaglia E, Gaia A. Active ageing in Europe: are changes in social capital associated with engagement, initiation and maintenance of activity in later life? Ageing \& Society. 2021:1-19. doi:10.1017/s0144686x21001021

91. Lakomý M. Differences in social participation of older adults across European welfare regimes: Fourteen years of SHARE data collection. International Sociology. 2021;36(6):906-25. doi:10.1177/0268580921993326

92. Rodríguez-Rodríguez V. Comprensión del envejecimiento activo según contextos. In: Fernández-Mayoralas G, Rojo-Pérez F, editors. Envejecimiento Activo, Calidad de Vida y Género Las miradas académica, institucional y social. Valencia: Tirant lo Blanch; 2021. p. 127-74. Available from: https://editorial.tirant.com/co/libro/envejecimiento-activo-calidad-de-vida-y-genero-9788418329142.

93. Golinowska S, Sowa A, Deeg D, Socci M, Principi A, Rodrigues R, et al. Participation in formal learning activities of older Europeans in poor and good health. European Journal of Ageing. 2016;13(2):115-27. doi:10.1007/s10433-016-0371-6

94. Wongsala M, Anbacken EM, Rosendahl S. Active ageing - perspectives on health, participation, and security among older adults in northeastern Thailand - a qualitative study. BMC Geriatrics. 2021;21(1):41. doi:10.1186/s12877-020-01981-2

95. Burr JA, Mutchler JE, Caro FG. Productive activity clusters among middle-aged and older adults: intersecting forms and time commitments. The Journals of Gerontology, Series B: Psychological Sciences and Social Sciences. 2007;62(4):S267-S75. doi:10.1093/geronb/62.4.s267

96. Pérez Díaz J, Abellán García A, Aceituno Nieto P, Ramiro Fariñas D. Un perfil de las personas mayores en España, 2020. Indicadores estadísticos básicos. Informes Envejecimiento en Red. 2020;25:1-39. http://envejecimiento.csic.es/documentos/documentos/enred-indicadoresbasicos2020.pdf

97. MSCBS- Ministerio de Sanidad CyBS. Encuesta Nacional de Salud de España 2017. Madrid: Ministerio de Sanidad, Consumo y Bienestar Social; 2017. Available from: 
https://www.mscbs.gob.es/estadEstudios/estadisticas/encuestaNacional/encuesta2017.htm.

98. Börsch-Supan A, Brugiavini A, Jürges H, Kapteyn A, Mackenbach J, Siegrist J, et al., editors. First Results from the Survey of Health, Ageing and Retirement in Europe (2004-2007). Starting the Longitudinal Dimension. Mannheim: Mannheim Research Institute for the Economics of Aging (MEA); 2008. Available from: http://www.share-project.org/uploads/tx_sharepublications/BuchSHAREganz250808.pdf.

99. Rodríguez-Rodríguez V, Rojo-Pérez F, Fernández-Mayoralas G, Ahmed-Mohamed K, Lardiés-Bosque R, PrietoFlores $\mathrm{ME}$, et al. Recursos económicos y calidad de vida en la población mayor. Revista Internacional de Sociología. 2011;69(1):195-227. doi:10.3989/ris.2009.11.26

100. Börsch-Supan A, Bristle J, Andersen-Ranberg K, Brugiavini A, Jusot F, Litwin H, et al., editors. Health and socioeconomic status over the life course First results from SHARE Waves 6 and 7. Olderbourg: De Gruyter Publishers; 2019. doi:10.1515/9783110617245 Available from:

https://www.degruyter.com/viewbooktoc/product/509241.

101. Chansarn S. Active ageing of elderly people and its determinants: Empirical evidence from Thailand. AsiaPacific Social Science Review. 2012;12(1):1-18.

102. Lai CKY, Chan EA, Chin KCW. Who are the healthy active seniors? A cluster analysis. BMC Geriatrics. 2014;14(127):1-7. doi:10.1186/1471-2318-14-127

103. Yang Y, Meng Y, Dong P. Health, Security and Participation: A Structural Relationship Modeling among the Three Pillars of Active Ageing in China. International Journal of Environmental Research and Public Health. 2020;17(19):7255. doi:10.3390/ijerph17197255

104. Mandl B, Millonig A, Friedl V. The Variety of the Golden Agers: Identifying Profiles of Older People for Mobility Research. Transportation Research Board 92nd Annual Meeting; Washington, DC: TRB committee ANB60 Safe Mobility of Older Persons; 2013.

105. da Silva Sousa NF, de Azevedo Barros MB. Level of active aging: Influence of environmental, social and healthrelated factors. Archives of Gerontology and Geriatrics. 2020;90:104094. doi:10.1016/j.archger.2020.104094

106. Rodríguez-Rodríguez V. Participación en actividades para envejecer activamente. In: Fernández-Mayoralas G, Rojo-Pérez F, editors. Envejecimiento Activo, Calidad de Vida y Género Las miradas académica, institucional y social. Valencia: Tirant lo Blanch; 2021. p. 231-66. Available from:

https://editorial.tirant.com/co/libro/envejecimiento-activo-calidad-de-vida-y-genero-9788418329142.

107. Lee HY, Jang SN, Lee S, Cho SI, Park EO. The relationship between social participation and self-rated health by sex and age: a cross-sectional survey. International Journal of Nursing Studies 2008;45(7):1042-54. doi:10.1016/j.jjnurstu.2007.05.007

108. Niedzwiedz CL, Richardson EA, Tunstall H, Shortt NK, Mitchell RJ, Pearce JR. The relationship between wealth and loneliness among older people across Europe: Is social participation protective? Preventive Medicine. 2016;91:24-31. doi:10.1016/j.ypmed.2016.07.016

109. Michèle J, Guillaume M, Alain T, Nathalie B, Claude F, Kamel G. Social and leisure activity profiles and wellbeing among the older adults: a longitudinal study. Aging \& Mental Health. 2019;23(1):77-83. doi:10.1080/13607863.2017.1394442

110. Mergenthaler A, Sackreuther I, Staudinger UM. Productive activity patterns among 60-70-year-old retirees in Germany. Ageing and Society. 2019;39(6):1122-51. doi:10.1017/S0144686X17001404

111. Fernández-Mayoralas G, Schettini R, Sánchez-Román M, Rojo-Pérez F, Agulló MS, Forjaz MJ. El papel del género en el buen envejecer. Una revisión sistemática desde la perspectiva científica. Prisma Social.

Page 23/28 
2018(21):149-76.

112. Solé-Auró A, Alcañiz M. Educational attainment, gender and health inequalities among older adults in Catalonia (Spain). International Journal for Equity in Health. 2016;15(1):126. doi:10.1186/s12939-016-0414-9

113. Foster L, Walker A. Gender and Active Ageing in Europe. European Journal of Ageing. 2013;10(1):3-10. doi:10.1007/s10433-013-0261-0

114. Del Barrio Truchado E, Marsillas Rascado S, Sancho Castiello M. Del envejecimiento activo a la ciudadanía activa: el papel de la amigabilidad. Aula Abierta. 2018;47(1):37-44. doi:10.17811/rifie.47.1.2018.37-44

115. Villar F, Serrat R. Aging at a development crossroad. In: Rojo-Pérez F, Fernández-Mayoralas G, editors. Handbook of Active Ageing and Quality of Life From Concepts to Applications. Cham: Springer, International Handbooks of Quality-of-Life series; 2021. p. 121-33. doi:10.1007/978-3-030-58031-5_7

116. Rodríguez-Rodriguez V, Rojo-Pérez F, Fernández-Mayoralas G. Active ageing in Spain: Leisure, Community Participation and Quality of Life. In: Rodriguez de la Vega L, Toscano W, editors. Handbook of Leisure, Physical Activity, Sports, Recreation, and Quality of Life. Cham: Springer International Publishing; 2018. p. 23757. doi:10.1007/978-3-319-75529-8_14

117. Dykstra PA, Fokkema T. Relationships between parents and their adult children: a West European typology of late-life families. Ageing and Society. 2011;31(4):545-69. doi:10.1017/S0144686X10001108

118. Petrová Kafková M. Older People as Care Givers and Their Roles In Family in the Era of Active Ageing: Case of the Czech Republic. Studia Socjologiczne. 2015;2(217):49-73.

119. Hajek A, König H-H. Which factors contribute to loneliness among older Europeans? Findings from the Survey of Health, Ageing and Retirement in Europe: Determinants of loneliness. Archives of Gerontology and Geriatrics. 2020;89:104080. doi:10.1016/j.archger.2020.104080

120. Puga D, Fernández-Carro C, Fernández-Abascal H. Multimorbidity, Social Networks and Health-Related Wellbeing at the End of the Life Course. In: Rojo-Pérez F, Fernández-Mayoralas G, editors. Handbook of Active Ageing and Quality of Life From Concepts to Applications. Cham: Springer, International Handbooks of Quality-of-Life series; 2021. p. 609-28. doi:10.1007/978-3-030-58031-5_37

121. Beridze G, Ayala A, Ribeiro O, Fernández-Mayoralas G, Rodríguez-Blázquez C, Rodríguez-Rodríguez V, et al. Are Loneliness and Social Isolation Associated with Quality of Life in Older Adults? Insights from Northern and Southern Europe. International Journal of Environmental Research and Public Health. 2020;17(22):8637. doi:10.3390/ijerph17228637

122. Rojo-Pérez F, Fernández-Mayoralas G, Rodríguez-Rodríguez V, Prieto-Flores ME, Rojo-Abuín JM. Residential Environment of the Elderly People in Spain. Towards a Municipal Categorization. Boletín de la Asociación de Geógrafos Españoles. 2007; (43):369-74. https://bage.age-geografia.es/ojs/index.php/bage/article/view/596

123. García Ballesteros A, Jiménez Blasco BC. Envejecimiento y urbanización: implicaciones de dos procesos coincidentes. Investigaciones Geográficas. 2016(89):58-73. doi:10.14350/rig.47362

124. Leeson GW. The Growth, Ageing and Urbanisation of our World. Journal of Population Ageing. 2018;11(2):10715. doi:10.1007/s12062-018-9225-7

125. Phillipson C, Grenier A. Urbanization and Ageing: Ageism, Inequality, and the Future of "Age-Friendly" Cities. University of Toronto Quarterly. 2021;90(2):225-41. doi:10.3138/utq.90.2.11

126. Beard JR, Petitot C. Ageing and urbanization: Can cities be designed to foster active ageing? Public Health Reviews. 2010;32(2):427-50. doi:10.1007/BF03391610 
127. Kaas L, Kocharkov G, Preugschat E. Wealth Inequality and Homeownership in Europe. Annals of Economics and Statistics. 2019;136:27-54. doi:10.15609/annaeconstat2009.136.0027

128. Rojo-Pérez F, Fernández-Mayoralas G, Rodríguez-Rodríguez V, Rojo-Abuín JM. The Environments of Ageing in the Context of the Global Quality of Life among Older People Living in Family Housing. In: Mollenkopf $\mathrm{H}$, Walker A, editors. Quality of Life in Old Age International and Multi-disciplinary Perspectives. Dordrecht: Springer, Social Indicators Research Series, Volume 31; 2007. p. 123-50. doi:10.1007/978-1-4020-5682-6_8

129. García-Valdez MT, Sánchez-González D, Román-Pérez R. Envejecimiento y estrategias de adaptación a los entornos urbanos desde la gerontología ambiental [Aging and adaptation strategies to urban environments from environmental gerontology]. Estudios Demográficos y Urbanos. 2019;34(1):101-28. doi:10.24201/edu.v34i1.1810

130. Marsillas S, De Donder L, Kardol T, van Regenmortel S, Dury S, Brosens D, et al. Does active ageing contribute to life satisfaction for older people? Testing a new model of active ageing. European Journal of Ageing. 2017;14(3):295-310. doi:10.1007/s10433-017-0413-8

131. Avramov D, Maskova M. Active ageing in Europe. Strasbourg: Council of Europe; 2003. Available from: https://book.coe.int/en/population-studies-series/2687-active-ageing-in-europe-volume-1-population-series-no41.html. accessed: 16-08-2021.

132. Bramanti D, Meda SG, Rossi G. Active Ageing among the Generations: Towards an Age-Friendly Society? In: Scabini E, Rossi G, editors. Living Longer A Resource for the family an Opportunity for Society. ChampaignIllinois: Common Ground Researc Networks; 2018. p. 1-34. Available from: http://hdl.handle.net/10807/127134.

133. Lee YS, Putnam M, Morrow-Howell N, Inoue M, Greenfield JC, Chen H. Consolidated Measures of Activity among Older Adults: Results of a Three Data Set Comparison. Journal of Gerontological Social Work. 2019;62(5):502-20. doi:10.1080/01634372.2019.1582123

134. Chen YC, Putnam M, Lee YS, Morrow-Howell N. Activity Patterns and Health Outcomes in Later Life: The Role of Nature of Engagement. The Gerontologist. 2019;59(4):698-708. doi:10.1093/geront/gny023

135. Boudiny K. 'Active ageing': From empty rhetoric to effective policy tool. Ageing and Society. 2013;33(6):107798. doi:10.1017/S0144686X1200030X

136. Pérez Díaz J, Abellán García A. "Active Ageing”: Its Relevance from an Historical Perspective. In: Rojo-Pérez F, Fernández-Mayoralas G, editors. Handbook of Active Ageing and Quality of Later Life From concepts to applications. Cham: Springer, series International Handbooks of Quality of Life; 2021. p. 171-84. doi:10.1007/978-3-030-58031-5_10

137. Fernández-Mayoralas G. Seguridad, envejecimiento activo y calidad de vida. In: Fernández-Mayoralas G, RojoPérez F, editors. Envejecimiento Activo, Calidad de Vida y Género Las miradas académica, institucional y social. Valencia: Tirant lo Blanch; 2021. p. 267-306. Available from:

https://editorial.tirant.com/co/libro/envejecimiento-activo-calidad-de-vida-y-genero-9788418329142.

138. Komp K, Johansson S. Population ageing in a lifecourse perspective: developing a conceptual framework. Ageing and Society. 2016;36(9):1937-60. doi:10.1017/S0144686X15000756

\section{Tables}

Table 1 to 4 is available in the Supplemental Files section. 
Figures

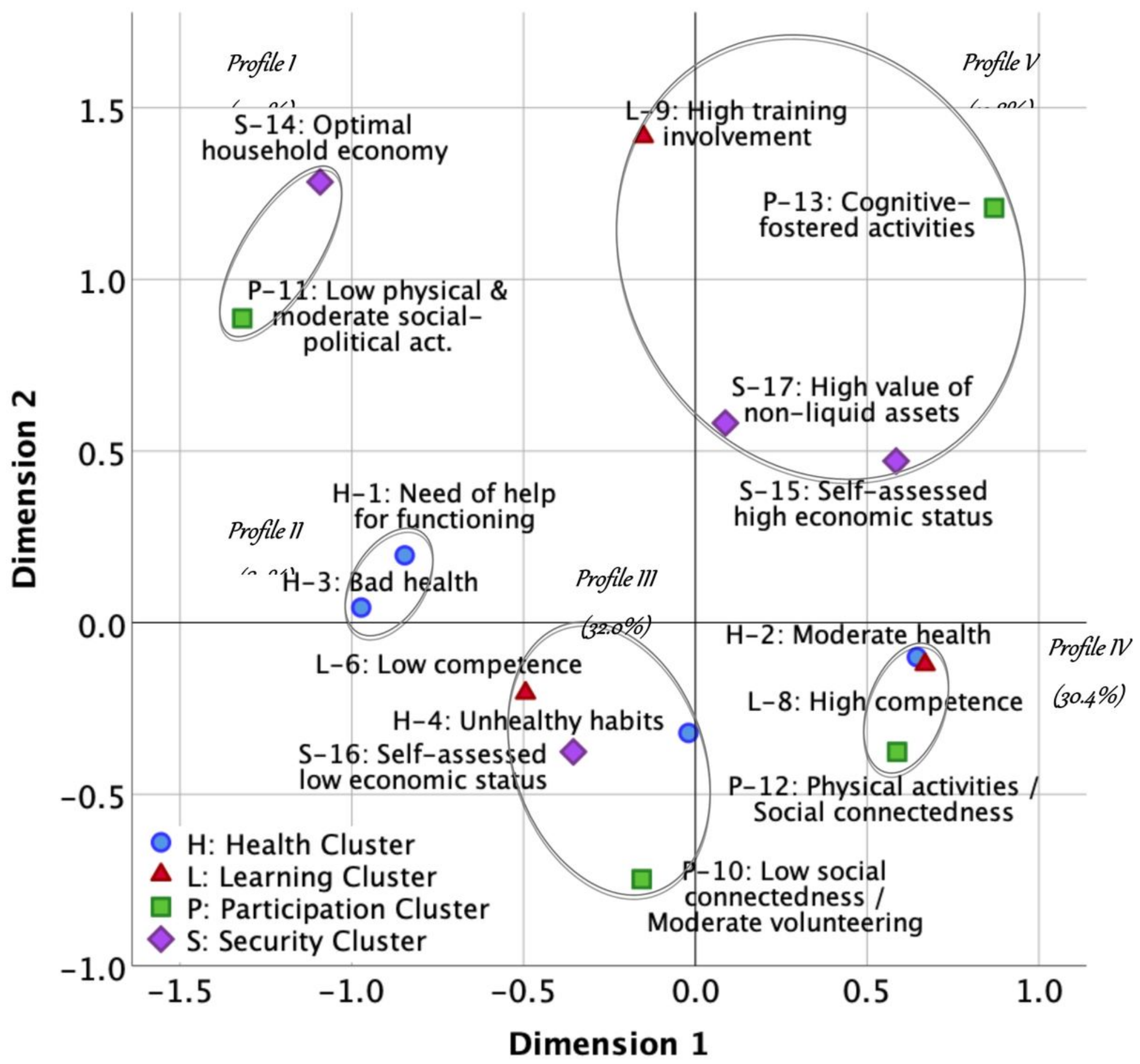

Figure 1

Plot of category clusters

Notes:

- Clusters are numbered correlatively through all clusters obtained in the analysis.

- Non-grouped clusters ( $\mathrm{H}-5$ : high hospital use \& L-7: competence \& training involvement) are no drawn in the figure. Coordinates: Cluster H-5: dimension 1: -2.232; dimension 2: 3.362. Cluster L-7: dimension 1: 1.273; 
dimension 2: 2.570

Profile I: people with moderate activity; Profile II: quasi-dependent persons; Profile III: people with active ageinglimiting conditions; Profile IV: people with diverse and balanced activity; Profile V: people with excellent active ageing conditions.
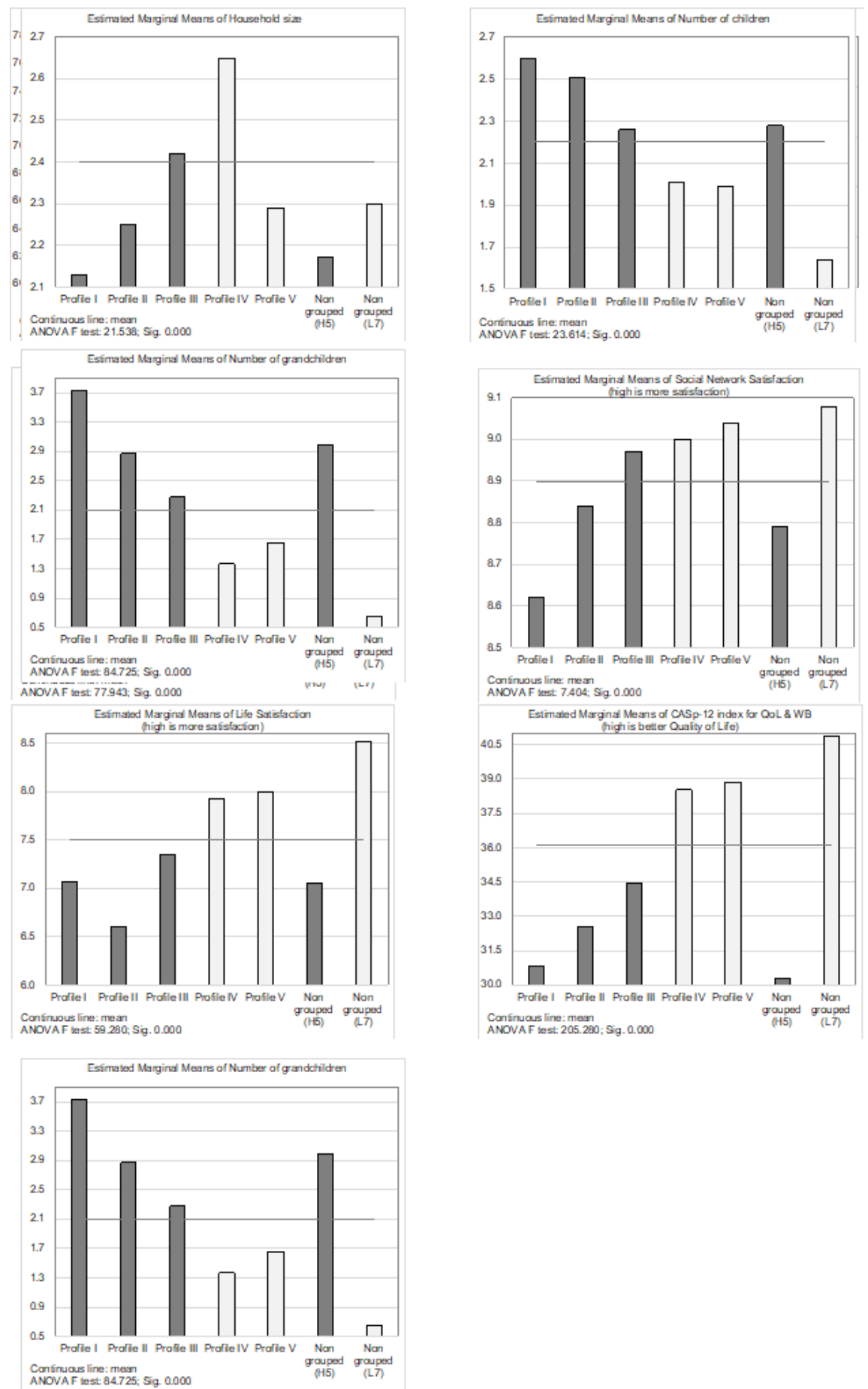

Figure 2

Active Ageing profiles plots according to personal and contextual characteristics

Notes: 
Profile I: people with moderate activity; Profile II: quasi-dependent persons; Profile III: people with active ageinglimiting conditions; Profile IV: people with diverse and balanced activity; Profile V: people with excellent active ageing conditions.

Profiles I, II, III and H5, on one hand, and profiles IV, V and L7, on the other hand, are coloured in dark or light grey, as results are under or over the mean values in all selected sociodemographic and contextual variables, respectively.

\section{Supplementary Files}

This is a list of supplementary files associated with this preprint. Click to download.

- Additionalfile1SelectedvariablesV23.xlsx

- Additionalfile2FactorAnalysisbyPrincipalV19.xIsx

- Table1CharacteristicsofthesampleV15.xIsx

- Table2ClusteranalysisV23.xlsx

- Table3ActiveAgeingProfilesMeansV23.xIsx

- Table4ActiveAgeingprofilescontingencyV19.xIsx 